\title{
GIS-BASED MAXIMUM COVERING LOCATION MODEL IN TIMES OF DISASTERS: THE CASE OF TUNCELI
}

\author{
Barış ÖZKAN ${ }^{1}$, Süleyman METE ${ }^{2}$, Erkan ÇELİK ${ }^{3}$, Eren ÖZCEYLAN ${ }^{4}$
}

\begin{abstract}
In times of disasters, accessing to shelters by the victims is a vital task in humanitarian logistics. One of the humanitarian logistics challenges is the difficulty involved in effectively coordinating large numbers of victims. Especially, the lack of spatial information involved in the rescue and recovery region is an obstacle for efficient planning. In this paper, a geographic information system (GIS)-based solution approach is developed to manage the assignments of victims to the shelters in times of disasters. To do so, the capacitated maximize coverage tool of ArcGIS is used and tested on the case of Tunceli city. As a result, different scenario analyses are generated under the distance and time restrictions between victims and shelters. Case results demonstrate the proposed approach's ability to support efficient and effective disaster management.
\end{abstract}

Keywords: Capacitated location-allocation, case study, disaster management, geographic information system, maximum covering.

Jel Classification: R53, C61, Q54.

\section{DOĞAL AFET DURUMU İÇİN CBS TABANLI MAKSIMUUM KAPSAMA YERLEŞIM MODELİ: TUNCELİ ÖRNEĞI}

\begin{abstract}
$\ddot{O} \mathbf{z}$
Afet zamanlarında insani lojistik açısından afetzedelerin barınma yerlerine erişimi önemli bir problemdir. İnsani lojistik yönetiminin önündeki en büyük zorluklardan biri de fazla sayıdaki afetzedelerin koordinasyonudur. Özellikle, olay mahallindeki mekânsal verinin eksikliği etkin bir planlamanın önündeki en büyük engellerden biridir. Bu çalışmada, afet zamanlarında kullanılmak üzere potansiyel afetzedelerin ilgili barınaklara atanması için Coğrafi Bilgi Sistemi (CBS) tabanlı bir çözüm yaklaşımı önerilmiştir. Ulaşılan afetzede sayısını maksimize etmek için ArcGIS'in maksimum kapsama yerleşim modeli kullanılmış ve Tunceli ili üzerinde test edilmiştir. Tunceli şehir merkezindeki 2.121 adet binaya 31.076 kişi, nüfus olarak atanmış ve 5 barınma merkezi ile model çalıştırılmıştır. Daha sonra farklı sayıda barınma merkezi ve kapsama alanları altında senaryo analizleri gerçekleştirilmiş ve sonuçlar yorumlanmıştır. Elde edilen sonuçlar, önerilen modelin afetzedelerin barınma merkezlerine atanmasında etkin bir araç olduğunu göstermiştir.
\end{abstract}

Anahtar Kelimeler: Kapasiteli yer tesisi, gerçek uygulama, afet yönetimi, coğrafi bilgi sistemi, maksimum kapsama.

Jel Sinıflama: R53, C61, Q54.

1 Asst. Prof. Barış Özkan, Samsun 19 Mayıs University, Faculty of Engineering, Department of Industrial Engineering, Samsun, Turkey, baris.ozkan@gmail.com ORCID: 0000-0001-7767-4087

2 Asst. Prof. Süleyman Mete, Munzur University, Faculty of Engineering, Department of Industrial Engineering, Tunceli, Turkey, suleymanmete@ munzur.edu.tr ORCID: 0000-0001-7631-5584.

3 Assoc. Prof. Erkan Çelik, Munzur University, Faculty of Engineering, Department of Industrial Engineering, Tunceli, Turkey, erkancelik@ munzur.edu.tr ORCID: 0000-0003-4465-0913

4 Assoc. Prof. Eren Özceylan, Gaziantep University, Faculty of Engineering, Department of Industrial Engineering, Gaziantep, Turkey, erenozceylan@gmail.com, ORCID: 0000-0002-5213-6335. 


\section{Introduction}

Most of the world's population lives in areas prone to natural disasters (Saeidian et al. 2018). Turkey is located in a seismically active region with relatively high records of earthquakes. Earthquakes often result in severe living loss and intensive economic and social problems. In disaster situations such as earthquakes, emergency services are faced with a large number of injured people, most of them with critical injuries, in which normal facilities and planning cannot respond (Tavakkoli-Moghaddam et al. 2018). To decrease the potential loss and manage efficient rescue plans are essentials.

In the literature, there are a lot of location-allocation model applications for the case of disasters or humanitarian logistics problems. A brief review is presented in Table 1. For a comprehensive review of facility location models for emergency humanitarian logistics, the reader is referred to Boonmee et al. (2017).

Table 1. Location -Allocation Models for Disaster Management

\begin{tabular}{|c|c|c|c|}
\hline Author(s) & Model & $\begin{array}{l}\text { Disaster or } \\
\text { Problem }\end{array}$ & Solution Tool \\
\hline Pan (2011) & P-median model & Typhoon & $\begin{array}{l}\text { Integer programming } \\
\text { Genetic algorithm }\end{array}$ \\
\hline $\begin{array}{l}\text { Fetter and Rakes } \\
\text { (2012) }\end{array}$ & $\begin{array}{l}\text { Obnoxious facility location } \\
\text { model }\end{array}$ & Debris disposal & $\begin{array}{l}\text { Mixed integer } \\
\text { programing }\end{array}$ \\
\hline Ye et al. (2015) & P-center model & Emergency rescue & $\begin{array}{l}\text { Variable neighborhood } \\
\text { search }\end{array}$ \\
\hline $\begin{array}{l}\text { Hashim et al. } \\
\text { (2017) }\end{array}$ & $\begin{array}{l}\text { Capacitated maximal covering } \\
\text { location model }\end{array}$ & Flood & Integer programming \\
\hline $\begin{array}{l}\text { Doungpan et al. } \\
\text { (2018) }\end{array}$ & $\begin{array}{l}\text { Maximal covering location } \\
\text { model }\end{array}$ & Emergency rescue & Integer programming \\
\hline $\begin{array}{l}\text { Zhang et al. } \\
(2019)\end{array}$ & Set covering model & $\begin{array}{l}\text { Air-ground } \\
\text { medical rescue }\end{array}$ & Integer programming \\
\hline This paper & $\begin{array}{l}\text { Capacitated maximal covering } \\
\text { location model }\end{array}$ & Emergency rescue & $\begin{array}{l}\text { Geographic } \\
\text { information system }\end{array}$ \\
\hline
\end{tabular}

This study applies a GIS tool namely capacitated maximum covering location model to provide an emergency plan in times of a disaster. The tool is tested on the case of Tunceli province. The aim of the study is to maximize the number of potential victims who can be allocated to the shelters within a safe fixed distance. Under the shelter capacity constraint, maximum number of people who may be affected by a disaster is assigned to a shelter. While people who are living in the residential area are considered as demand, the shelters which are located in different districts are considered as source nodes. The problem is solved using ArcGIS software.

The paper is organized as follows. Next section presents the related tool of ArcGIS. The third part describes the case study with data and presents the solutions. Finally the last part presents conclusions and directions for future research.

\section{Application Of GIS Tool}

In this paper, the capacitated maximum covering location model developed by Haghani (1996) is applied. Due to the size of the problem, the location tool of ArcGIS is used to run the model. To apply the model for the case of Tunceli, first of all, the locations of residential buildings and road data are gathered from www.openstreetmap.com 
While the data of buildings are based on polygon, roads are recorded as vectors. Unnecessary locations like bus stations, electricity lines, cafeterias and etc. are removed using Global Mapper 18 software. The map which includes the residential buildings and roads is finalized using ArcGIS 10.4 (Figure 1).

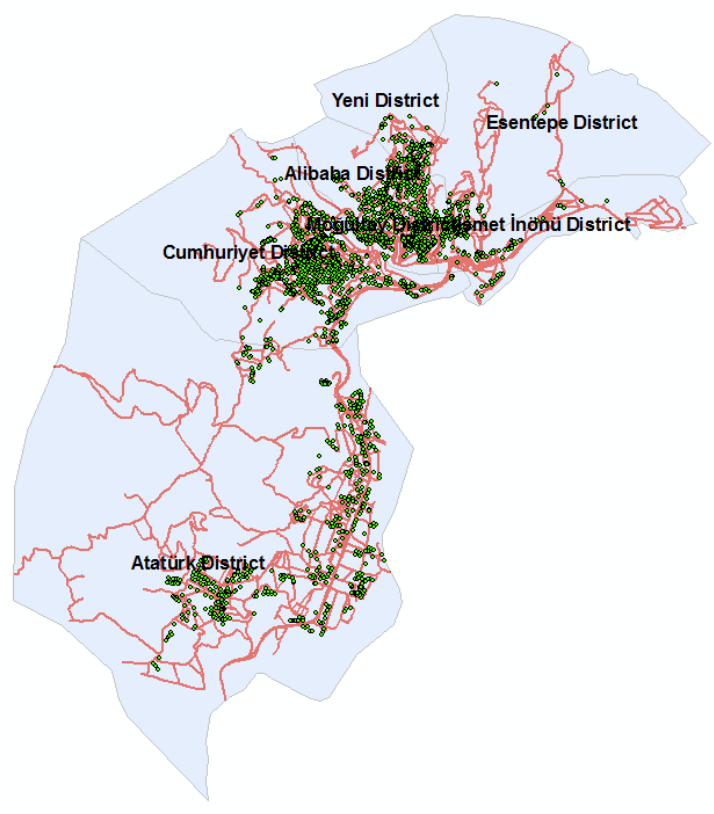

Figure 1. Road Network and Residential Area in Tunceli.

After locating the residential buildings, population data which is collected from Turkish Statistical Institute is assigned to each building. Figure 2 shows an interface of population assignment to 2121 different buildings.

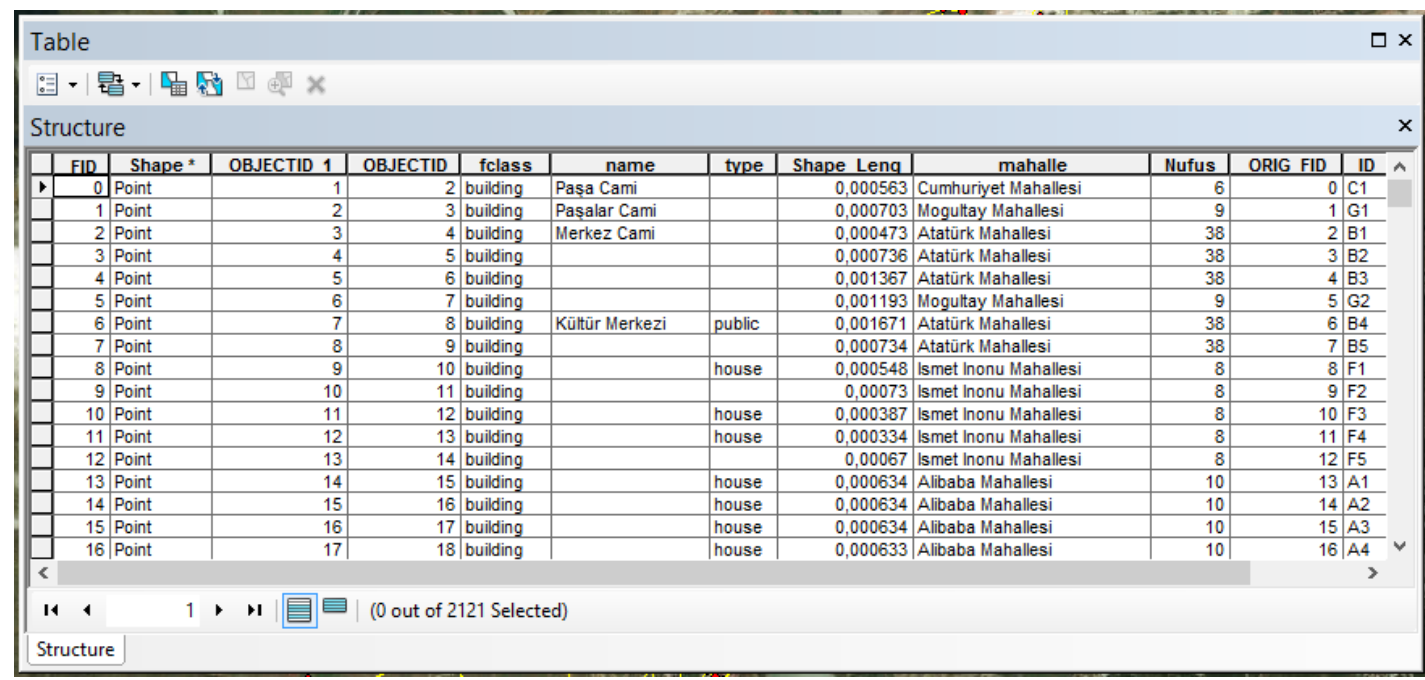

Figure 2. Population Assignment to the Buildings.

After the population assignment to the buildings, 5 different locations are selected for shelters randomly and the capacities of those shelters are determined to cover the population (Figure 3 ). 


\begin{tabular}{|c|c|c|c|c|c|c|c|}
\hline \multicolumn{3}{|l|}{ Table } & & & & & $\square \times$ \\
\hline \multicolumn{8}{|c|}{ 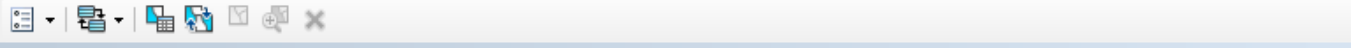 } \\
\hline \multicolumn{3}{|l|}{ Shelter land } & & & & & $x$ \\
\hline \begin{tabular}{l|l|l} 
FID & Shape * \\
\end{tabular} & \begin{tabular}{|l|l|} 
OBJECTID & fclass \\
\end{tabular} & name & type & Shape Leng & Shape Area mahalle & Nufus & ORIG FID \\
\hline D Point & 0 S1 & toplama merkezi 1 & afad & 0 & 0 & 8000 & 0 \\
\hline - 11 Point & $\begin{array}{ll}0.52 \\
0.53\end{array}$ & toplama merkezi 2 & stadyum & 0 & 0 & $\frac{10000}{5000}$ & 1 \\
\hline 2 Point & 0 S3 & toplama merkezi 3 & & 0 & 0 & 5000 & \\
\hline \begin{tabular}{l|l|l|l|l|l}
3 & Point \\
& Point
\end{tabular} & $\begin{array}{lll}0 & 54 \\
0 & 55\end{array}$ & toplama merkezi 4 & & 0 & 0 & 6000 & 0 \\
\hline $4 \mid$ Point & $0 \mid \$ 5$ & toplama merkezi 5 & & 0 & 0 & 3000 & 0 \\
\hline
\end{tabular}

Figure 3. Data of the Five Shelters.

To make a network analysis within ArcGIS, a network dataset is needed to be created. While the type of network dataset is shape file-based network dataset, the elements are 1396 junctions and 3312 edges. After the creating the network, Network Analyst section of ArcGIS is used. In the Network Analyst section, there are different types of location-allocation models. In our problem, Maximize Capacitated Coverage tool is used (Figure 4).

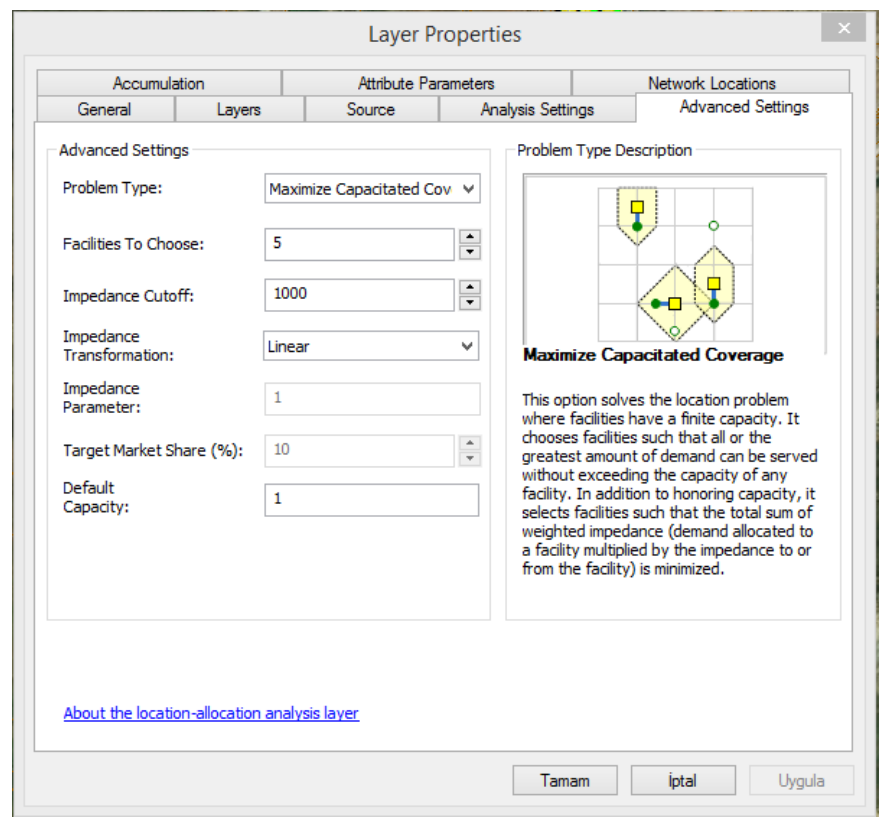

Figure 4. Maximize Capacitated Coverage Tool in GIS.

In Figure 4, there are mainly two parameters which are facilities to choose and impedance cutoff. The first one is used to determine the number of shelters to be opened. The second one is used to determine the distance limit to be covered by a shelter. It must be noted that the applied maximize capacitated coverage tool belongs to ArcGIS software. In the computational analysis section, a combination of these two parameters is used in the case study and the results are demonstrated.

\section{Case Study}

In this paper, the capacitated maximum covering location model is applied to the case of Tunceli province (Figure 5). Tunceli province is located in the middle of Eastern Anatolia Region and its population was 88,198 in 2018 . 
According to the Informatics Inventory of Spatial and Statistical Distribution of Disasters in Turkey, Tunceli is ranked 5th among the other provinces, which are affected most from disasters, on the basis of incidents (Erzurum, Trabzon, Bingöl, Rize, Tunceli) (Dal et al. 2017).

Many natural disasters have occurred including the ones reported as landslide, rock fall, avalanche, fire and flood with earthquake since 1958 in Tunceli province. There have been several earthquakes of magnitude 5 or higher in Tunceli province, a tectonically active and the surrounding territory through its history (Onat and Yön, 2018).

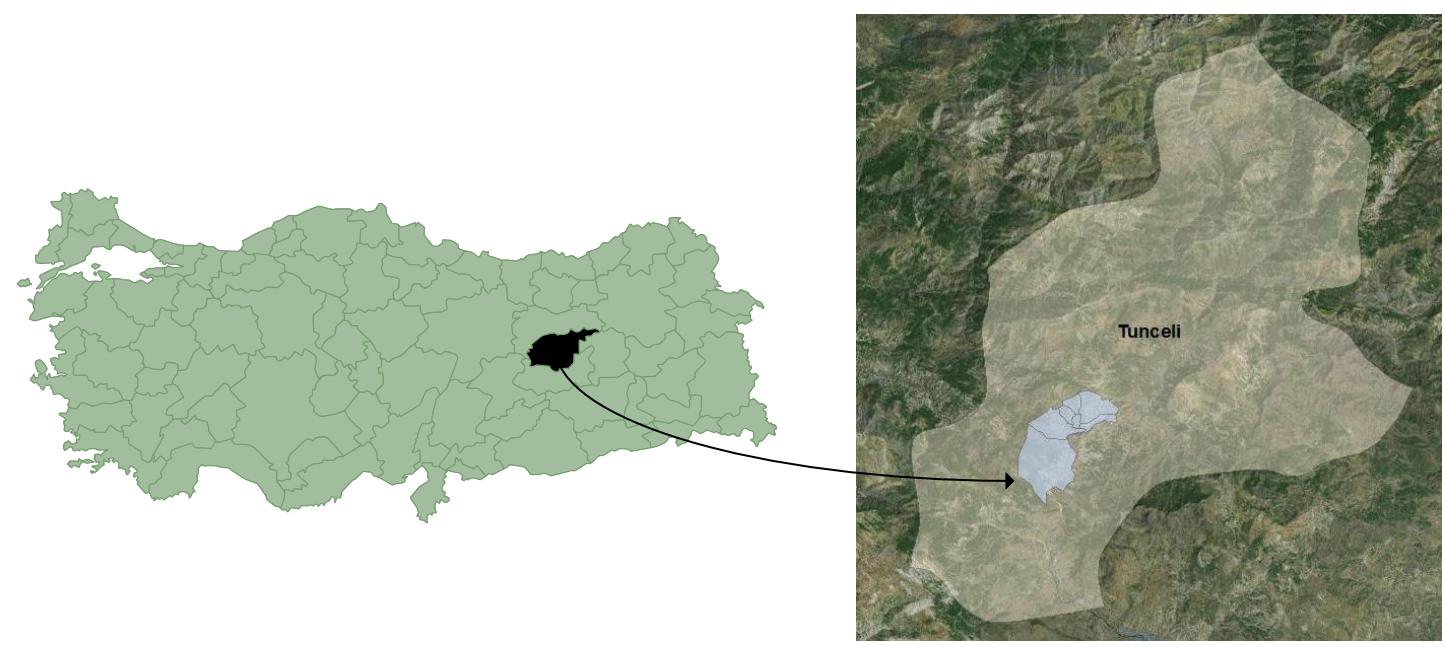

Figure 5. Study Area.

Our focus is the city center of Tunceli rather than the rural area. Therefore, 7 main districts of Tunceli which cover $35 \%$ of total population are considered as the study area. The buildings and residential area are located in 7 main districts of Tunceli. Rest of Tunceli is rural area. The number of buildings, the average population per buildings and the population of each district are given in Table 2 .

Table 2. Data Related with the Districts

\begin{tabular}{|c|c|c|c|c|}
\hline No & Name of District & Number of building & $\begin{array}{r}\text { Ave. population per } \\
\text { building }\end{array}$ & Total population \\
\hline D1 & Alibaba District & 252 & 10 & 2520 \\
\hline D2 & Atatürk District & 484 & 38 & 18392 \\
\hline D3 & Cumhuriyet District & 738 & 6 & 4428 \\
\hline D4 & Esentepe District & 115 & 10 & 1150 \\
\hline D5 & İsmet İnönü District & 72 & 8 & 576 \\
\hline D6 & Moğultay District & 330 & 9 & 2970 \\
\hline D7 & Yeni District & 130 & 8 & 1040 \\
\hline & Total & 2121 & & 31076 \\
\hline
\end{tabular}


Gönderim tarihi: 29.08.2019 Kabul tarihi: 01.10.2019

DOI: 10.14514/BYK.m.26515393.2019.sp/100-111

While the districts with the located buildings are shown in Figure 6, the locations of 5 shelters are shown in Figure 7.

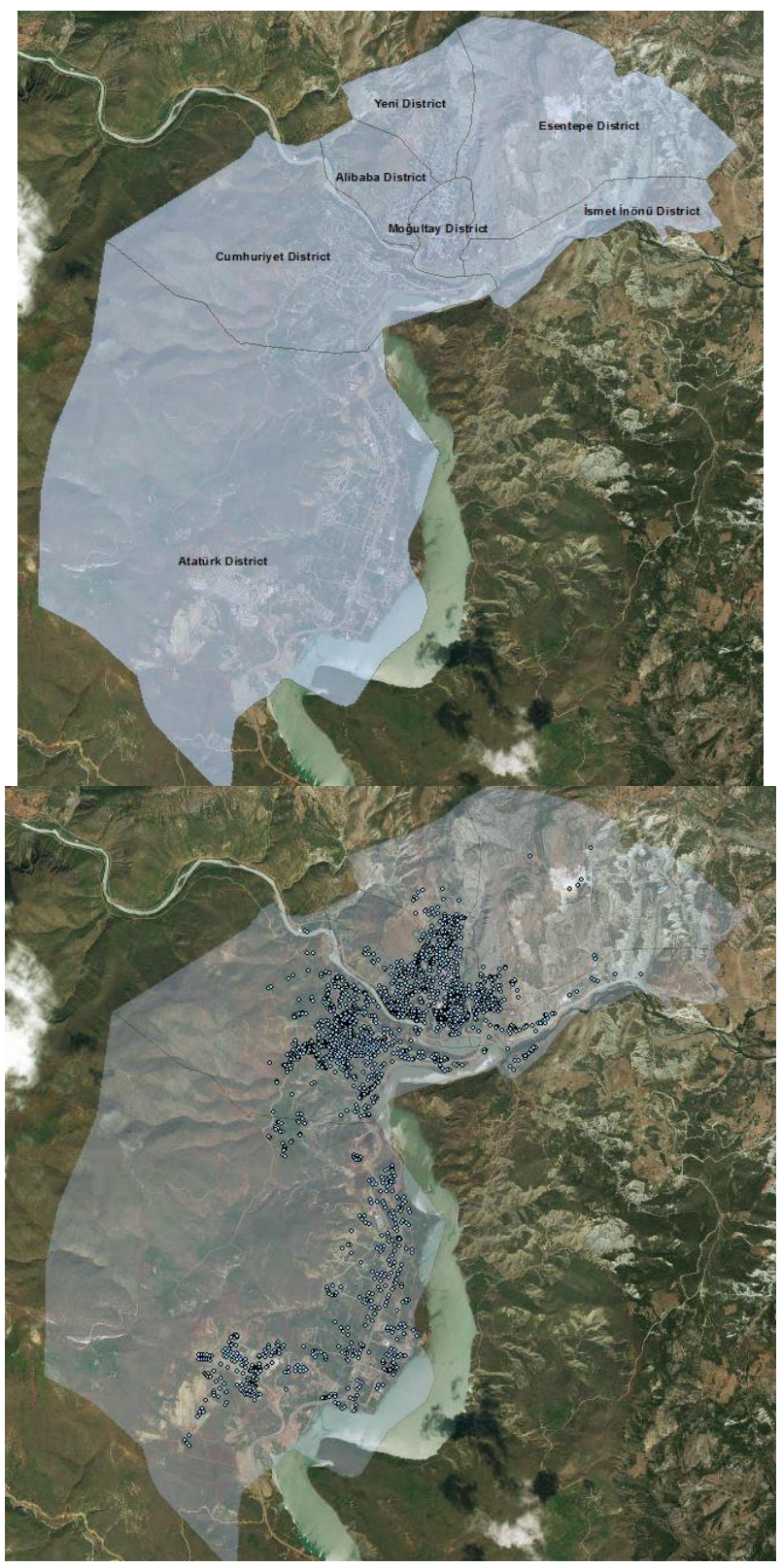

Figure 6. The Borders of Districts (left) and Covered Buildings (right). 


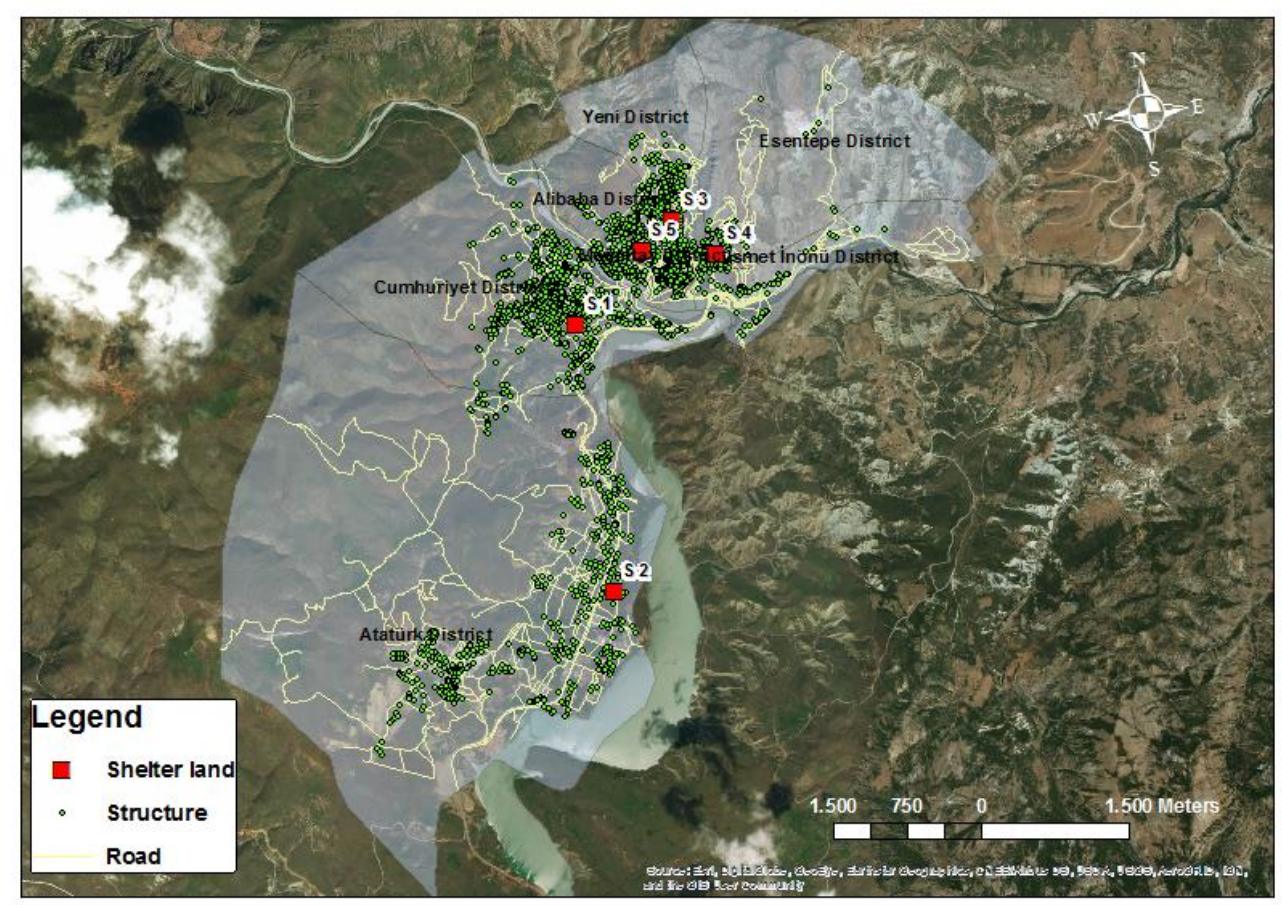

Figure 7. Locations of the Shelters.

Using the number of shelters and distance limit, 25 different problems are solved in ArcGIS tool. The detailed results of each problem are given in Table 3. All problems are run using a PC with Intel Core7 $3.06 \mathrm{GHz}$ and $8 \mathrm{~GB}$ RAM. The computation time for each problem is less than 5 seconds.

According to the results and input data, maximum percentage of covered people is $47.4 \%$. This percentage is obtained when the number of opened shelters is 5 and distance limit is 1000 meters. When the number of shelters and the distance limit is increased, it is an expected situation that the coverage percentage also increases. The assignments of $5^{\text {th }}, 10^{\text {th }}, 15^{\text {th }}, 20^{\text {th }}$ and $25^{\text {th }}$ problems are illustrated in Figure 8 . It must be noted that the obtained results are not tested optimally. It means that the results may be optimal or not. 
Table 3. Results of the Model

\begin{tabular}{|c|c|c|c|c|c|c|c|}
\hline \multirow{2}{*}{ Problem } & \multirow{2}{*}{$\begin{array}{l}\text { Number of } \\
\text { shelter }\end{array}$} & \multirow{2}{*}{$\begin{array}{l}\text { Distance limit } \\
\text { (m) }\end{array}$} & \multirow{2}{*}{$\begin{array}{l}\text { Opened } \\
\text { shelter }\end{array}$} & \multicolumn{2}{|c|}{$\begin{array}{l}\text { Covered } \\
\text { buildings }\end{array}$} & \multicolumn{2}{|c|}{ Covered people } \\
\hline & & & & Unit & $\%$ & Number & $\%$ \\
\hline 1 & 1 & 100 & S4 & 13 & 0.006 & 130 & 0.004 \\
\hline 2 & 1 & 250 & S4 & 45 & 0.021 & 446 & 0.014 \\
\hline 3 & 1 & 500 & S3 & 223 & 0.105 & 2034 & 0.065 \\
\hline 4 & 1 & 750 & S3 & 498 & 0.235 & 4494 & 0.145 \\
\hline 5 & 1 & 1000 & S3 & 552 & 0.260 & 5000 & 0.161 \\
\hline 6 & 2 & 100 & S3-S4 & 22 & 0.010 & 211 & 0.007 \\
\hline 7 & 2 & 250 & S2-S4 & 55 & 0.026 & 826 & 0.027 \\
\hline 8 & 2 & 500 & S1-S3 & 421 & 0.199 & 3222 & 0.104 \\
\hline 9 & 2 & 750 & S1-S3 & 924 & 0.436 & 7050 & 0.227 \\
\hline 10 & 2 & 1000 & S2-S3 & 664 & 0.313 & 9256 & 0.298 \\
\hline 11 & 3 & 100 & S2-S3-S4 & 24 & 0.011 & 287 & 0.009 \\
\hline 12 & 3 & 250 & S2-S3-S4 & 96 & 0.045 & 1202 & 0.039 \\
\hline 13 & 3 & 500 & S1-S2-S3 & 449 & 0.212 & 4286 & 0.138 \\
\hline 14 & 3 & 750 & S1-S2-S3 & 987 & 0.465 & 9444 & 0.304 \\
\hline 15 & 3 & 1000 & S1-S2-S3 & 1183 & 0.558 & 12370 & 0.398 \\
\hline 16 & 4 & 100 & S1-S2-S3-S4 & 33 & 0.016 & 341 & 0.011 \\
\hline 17 & 4 & 250 & S1-S2-S3-S4 & 141 & 0.067 & 1472 & 0.048 \\
\hline 18 & 4 & 500 & S1-S2-S3-S4 & 552 & 0.260 & 5289 & 0.170 \\
\hline 19 & 4 & 750 & S1-S2-S3-S4 & 1109 & 0.523 & 10609 & 0.341 \\
\hline 20 & 4 & 1000 & S1-S2-S3-S4 & 1329 & 0.627 & 13788 & 0.444 \\
\hline 21 & 5 & 100 & $\begin{array}{l}\text { S1-S2-S3- } \\
\text { S4-S5 }\end{array}$ & 37 & 0.017 & 377 & 0.012 \\
\hline 22 & 5 & 250 & $\begin{array}{l}\text { S1-S2-S3- } \\
\text { S4-S5 }\end{array}$ & 149 & 0.070 & 1547 & 0.050 \\
\hline 23 & 5 & 500 & $\begin{array}{l}\text { S1-S2-S3- } \\
\text { S4-S5 }\end{array}$ & 578 & 0.273 & 5533 & 0.178 \\
\hline 24 & 5 & 750 & $\begin{array}{l}\text { S1-S2-S3- } \\
\text { S4-S5 }\end{array}$ & 1208 & 0.570 & 11574 & 0.372 \\
\hline 25 & 5 & 1000 & $\begin{array}{l}\text { S1-S2-S3- } \\
\text { S4-S5 }\end{array}$ & 1429 & 0.674 & 14716 & 0.474 \\
\hline
\end{tabular}



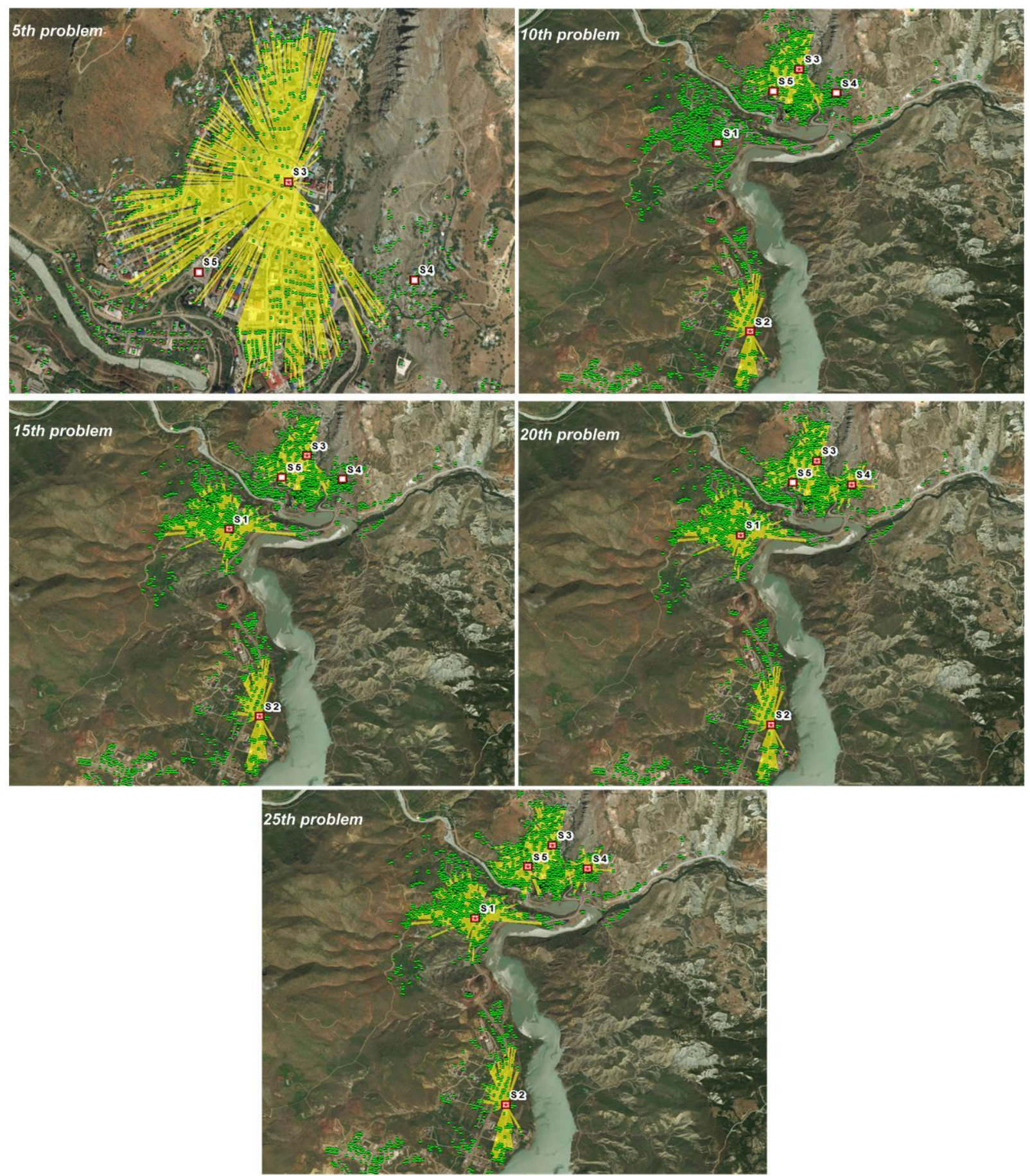

Figure 8. The Assignments of the Cases with 1000 meters Distance Limit.

To increase the coverage percentage and see when $100 \%$ coverage is achieved, the distance limit is maximized. Under the capacity constraints, all the potential victims are fully covered when the distance limit is $9200 \mathrm{~m}$. The illustration of the case with $9200 \mathrm{~m}$ distance limit is given in Figure 9. 


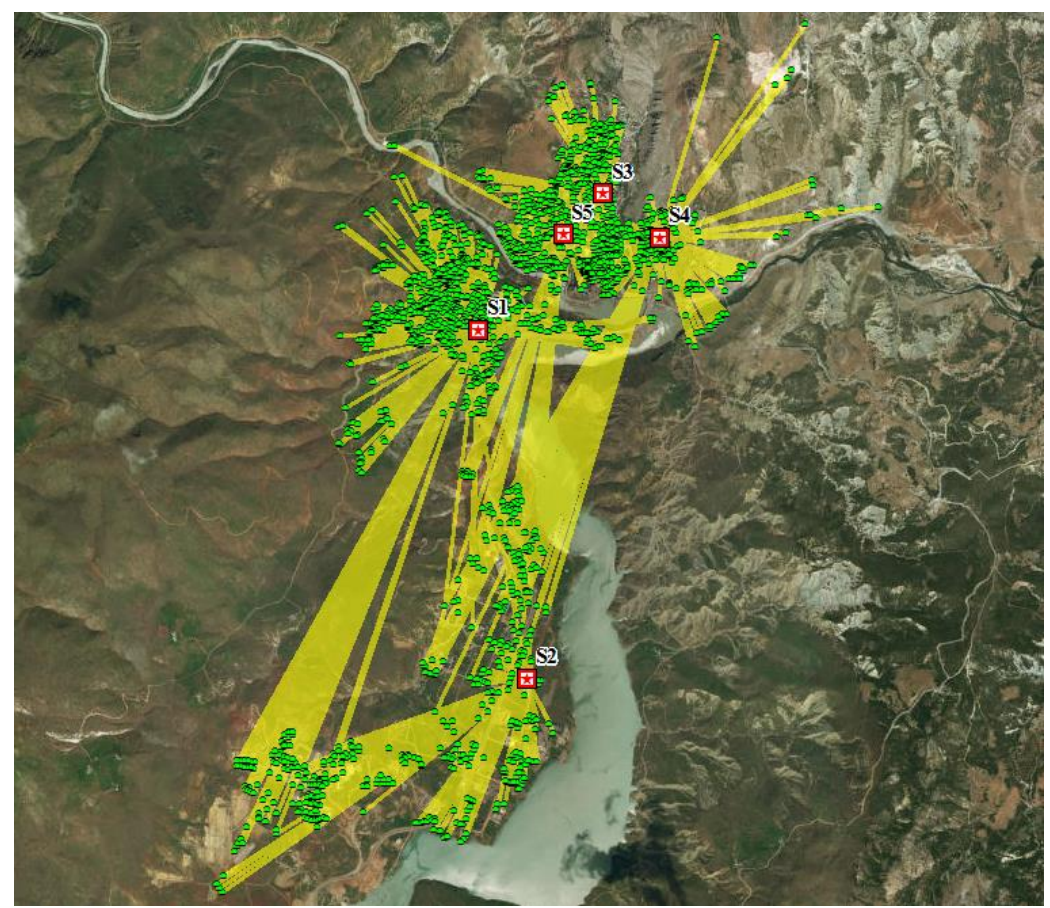

Figure 9. 100\% Coverage with 9200m Distance Limit

It is a known fact that capacity consideration forces these kinds of models negatively. To overcome this issue, a new solution is also generated by ignoring the capacities of shelters. In this case, $100 \%$ coverage is also achieved when the distance limit is $4700 \mathrm{~m}$. It means that ignoring the capacities decreases the distance limit from $9200 \mathrm{~m}$ to $4700 \mathrm{~m}$ by almost $50 \%$. Figure 10 shows the assignments of all potential victims to the un-capacitated shelters under 4700m distance limit.

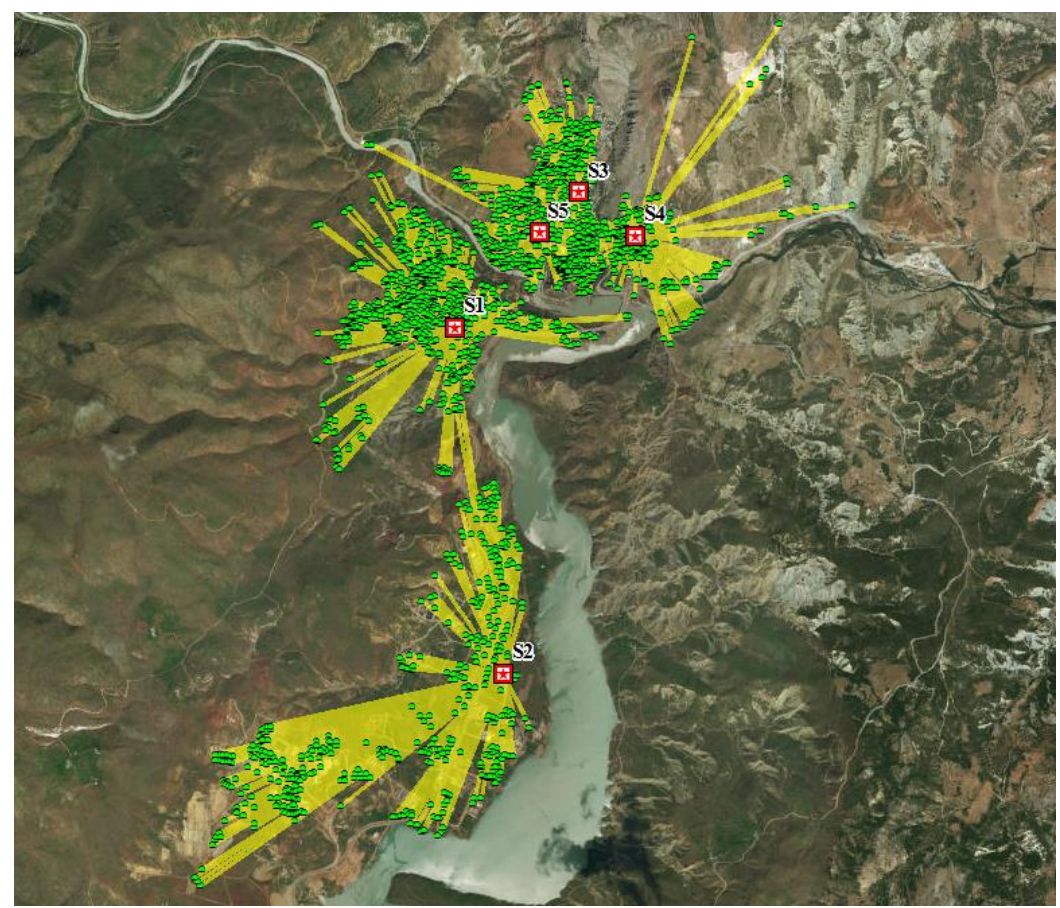

Figure 10. 100\% Coverage with 4700m Distance Limit with un-capacitated Shelters 


\section{Conclusion}

In this paper, a rescue plan in times of a disaster is investigated for Tunceli province. Our aim is to analyze the access of potential victims to the shelters by maximizing the covered potential victims. To do so, the problem is considered as a capacitated maximum covering location model. To solve the model, the location-allocation tool of ArcGIS is used. In the case study, 5 shelters are considered as source nodes while 31,076 people are considered as potential victims (demand nodes). In the analysis part, 25 problems are generated and solved to provide managerial insights for the decision makers. As a result, different what-if scenario analyses demonstrate that half of the population can be covered with 5 shelters in $1 \mathrm{~km}$ distance. Finally, two extra analyses are conducted to see at which distance limit $100 \%$ coverage is achieved. When the capacities are not ignored, all potential victims are served less than 9200m distance limit. Conversely, 4700m distance limit is enough to cover all people by ignoring the capacities. For the future studies, $(i)$ other location-allocation models such as p-median, set covering and etc. should be applied and (ii) a web-based decision support system should be developed.

\section{References}

Boonmee, C., Arimura, M. \& Asada, T. (2017). Facility location optimization model for emergency humanitarian logistics. International Journal of Disaster Risk Reduction, 24, 485-498.

Dal, M., Öcal, A.D. \& Göktepe, D. (2017). Natural disaster of Tunceli province and its environment. Proceedings of 4th International Regional Development Conference, Tunceli (pp. 601-607).

Doungpan, S., Moryadee, S., U-Tapao, C. \& Laokhongthavorn, Z. (2018). Analysis of three emergency medical location models: A case study of Thailand. Proceedings of International Conference on System Science and Engineering (pp. 1-6).

Fetter, G. \& Rakes, T. (2012). Incorporating recycling into post-disaster debris disposal. SocioEconomic Planning Sciences, 46(1), 14-22.

Haghani, A. (1996). Capacitated maximum covering location models: Formulations and solution procedures. Journal of Advanced Transportation, 30(3), 101-136.

Hashim, N.M., Shariff, S.S.R. \& Deni, S.M. (2017). Capacitated maximal covering location allocation problem during flood disaster. Advanced Science Letters, 23(11), 1154511548 .

Onat, O. \& Yön, B. (2018). Earthquake risk amplification based on architectural plan irregularity. Proceedings of 2nd International Symposium on Natural Hazards and Disaster Management, Sakarya (pp. 665-674).

Pan, A.-P. (2011). A constructive genetic algorithm for the P-median location problem of typhoon emergency shelter in China coastal rural areas. Key Engineering Materials, 480-481, 1215-1220.

Saeidian, B., Mesgari, M.S., Pradhan, B. \& Ghodousi, M. (2018). Optimized location-allocation of earthquake relief centers using PSO and ACO, Complemented by GIS, Clustering, and TOPSIS. ISPRS International Journal of Geo-Information, 7(8), 1-25.

Tavakkoli-Moghaddam, R., Memari, P. \& Talebi, E. (2018). A bi-objective location-allocation problem of temporary emergency stations and ambulance routing in a disaster situation. Proceedings of 4th International Conference on Optimization and Applications, Morocco (pp. 1-4).

Ye, F., Zhao, Q., Xi, M. \& Dessouky, M. (2015). Chinese national emergency warehouse location research based on VNS algorithm. Electronic Notes in Discrete Mathematics, 47, 61-68. 
Beykoz Akademi Dergisi, 2019; Özel Sayı

MAKALE

Gönderim tarihi: 29.08.2019 Kabul tarihi: 01.10.2019

DOI: 10.14514/BYK.m.26515393.2019.sp/100-111

Zhang, M., Zhang, Y., Qiu, Z. \& Wu, H. (2019). Two-stage covering location model for airground medical rescue system. Sustainability, 11(12), 3242. 